\title{
The first fossil brown lacewing from the Miocene of the Tibetan Plateau (Neuroptera, Hemerobiidae)
}

\author{
Qiang Yang ${ }^{1,2,3}$, Chaofan $\mathrm{Shi}^{2,4}$, Xiangchuan $\mathrm{Li}^{5}$, Hong Pang', Dong Ren ${ }^{2}$
}

I State Key Laboratory of Biocontrol, Key Laboratory of Biodiversity Dynamics and Conservation of Guangdong Higher Education Institute, Ecology and Evolution, School of Life Sciences, Sun Yat-sen University, Guangzhou 510275, PR China 2 College of Life Sciences, Capital Normal University, Xisanhuanbeilu 105, Haidian District, Beijing 100048, PR China 3 Geoscience Museum, Hebei GEO University, 136 Huaiandonglu, Shijiazhuang, 050031, PR China 4 School of Earth Science and Engineering, Sun Yat-sen University, Guangzhou 510275, PR China 5 College of Earth Sciences and Resources \& Key Laboratory of Western Mineral Resources and Geological Engineering of the Ministry of Education, Chang'an University, Xian 710054, PR China

Corresponding author: Hong Pang (lsshpang@mail.sysu.edu.cn); Dong Ren (rendong@mail.cnu.edu.cn)

Academic editor:S. Winterton | Received 19 September 2017 | Accepted 28 November 2017 | Published 10 January 2018

http://zoobank.org/CB11801F-235E-4F63-A34A-E4C03F2991EO

Citation: Yang Q, Shi C, Li X, Pang H, Ren D (2018) The first fossil brown lacewing from the Miocene of the Tibetan Plateau (Neuroptera, Hemerobiidae). ZooKeys 726: 145-154. https://doi.org/10.3897/zookeys.726.21086

\begin{abstract}
A new species of Hemerobiidae, Wesmaelius makarkini Yang, Pang \& Ren, sp. n. is described from the Lower Miocene, Garang Formation of Zeku County, Qinghai Province (northeastern Tibetan Plateau), China. The species is assigned to the widely distributed extant genus Wesmaelius Krüger (Hemerobiinae). The species represents the first named fossil of this family from China, which sheds light on the historical distribution of Wesmaelius and early divergences within Hemerobiinae.
\end{abstract}

\section{Keywords}

Cenozoic, China, Wesmaelius

\section{Introduction}

Hemerobiidae, commonly known as brown lacewings, are the third largest family of Neuroptera, with about 520 species assigned to 27 genera (Oswald 2017). Hemerobiids are the most widely distributed lacewings, from subpolar tundra to tropical regions 
(Oswald 1993, 2017; Monserrat 2000; Makarkin et al. 2016). The extant brown lacewings have been comprehensively studied by Oswald (1993) including a taxonomic revision, a genus-level phylogeny based on morphology, and the establishment of a subfamilial classification. Recently, Garzón-Orduña et al. (2016) provided a total evidence phylogeny of the family based on combined data of morphological characters and DNA. As a result, seven known subfamilies were recovered to be monophyletic, with the addition of a new subfamily and the revision of Notiobiellinae (Garzón-Orduña et al. 2016).

Compared with its putative sister group Chrysopidae, Hemerobiidae have a relatively sparse and recent fossil record (Haring and Aspöck 2004; Winterton et al. 2010; Wang et al. 2016), although in a recent study, Hemerobiidae are not sister to Chrysopidae, but to the clade including Mantispoidea, Chrysopoidea, and Myrmeleontoidea (Winterton et al. 2017). Only four species have been described from the Mesozoic, with the earliest from the Late Jurassic. All the other 19 species have been described from the Cenozoic, from the Eocene to the Miocene (Makarkin et al. 2003, 2016; Engel and Grimaldi 2007) (Table 1). The Mesozoic hemerobiids comprise four monotypic extinct genera, one from the Late Jurassic of Kazakhstan, two from the Early Cretaceous of Mongolia and England, and one from the Late Cretaceous of Canada (Panfilov 1980; Ponomarenko 1992; Jepson et al. 2012; Klimaszewski and Kevan 1986; Makarkin et al. 2003, 2016). In the Cenozoic, 10 genera have been described from Russia, Baltic amber, Denmark, England, Canada, USA, and Dominican amber (Pictet-Baraban and Hagen 1856; Scudder 1878, 1890; Henriksen 1922; Krüger 1923; Jarzembowski 1980; Makarkin 1991; Oswald 2000; Makarkin et al. 2003; Makarkin and Wedmann 2009; Jepson et al. 2010), as well as China in this paper.

Fossil hemerobiids have never been described from China. Mesohemerobius jeholensis Ping, from the Lower Cretaceous, Yixian Formation of China, was previously placed in Hemerobiidae, but was later excluded from the family by Makarkin et al. (2003) and referred as Neuroptera incertae sedis. Wang et al. (2014) mentioned hemerobiids in Fushun amber, but with no descriptions or figures. Herein, we describe a new species of Wesmaelius Krüger (Hemerobiidae: Hemerobiinae) from the Lower Miocene of the northeastern Tibetan Plateau in China. The species is the first named fossil of the family Hemerobiidae in China.

\section{Materials and methods}

The specimen was collected from the Guide Group at Caergen Village, Duohemao

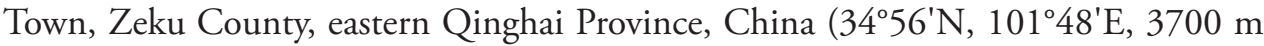
a.s.l.) (fig. 1 in $\mathrm{Li}$ et al. 2017). The stratum is a papery oil shale deposit and constitutes a lacustrine-fluvial sedimentary succession (fig. 1 in Li et al. 2016), belonging to the Garang Formation (<16-19 Ma), the Lower Miocene. The deposit yielded abundant, exquisitely preserved fossil plants (Guo 1980; Fang et al. 2005, 2007), bird feathers (Yang 1975), and insects including representatives of Hemiptera (Li et al. 2017), Diptera, Hymenoptera, Neuroptera, Mecoptera, Odonata and Coleoptera (pers. obs.). 
Table I. List of Named Fossil Hemerobiidae (updated from Engel and Grimaldi 2007).

\begin{tabular}{|c|c|c|}
\hline Taxon & Deposit & Reference \\
\hline Drepanepteryx oedobia Makarkin & Miocene, Russia & Makarkin 1991 \\
\hline Drepanepteryx ramosa Makarkin & Miocene, Russia & Makarkin 1991 \\
\hline Hemerobius incertus Makarkin & Miocene, Russia & Makarkin 1991 \\
\hline Hemerobius prohumulinus Makarkin & Miocene, Russia & Makarkin 1991 \\
\hline Megalomus caucasicus Makarkin & Miocene, Russia & Makarkin 1991 \\
\hline Megalomus sikhotensis Makarkin & Miocene, Russia & Makarkin 1991 \\
\hline Notiobiella thaumasta Oswald & Miocene, Dominican amber & Oswald 1999 \\
\hline Wesmaelius makarkini sp. $\mathrm{n}$. & Miocene, China & This paper \\
\hline Bothromicromus lachlani Scudder & Oligocene, Canada & Scudder 1878 \\
\hline Drepanepteryx resinata (Krüger, 1923) & Eocene, Baltic amber & Krüger 1923; Makarkin et al. 2016 \\
\hline Megalomus tinctus (Jarzembowski) & Eocene, England & Jarzembowski 1980; Makarkin 1991 \\
\hline Prolachlanius resinatus (Hagen) & Eocene, Baltic amber & $\begin{array}{l}\text { Pictet-Baraban and Hagen 1856; } \\
\text { Krüger 1923; Makarkin et al. } 2012\end{array}$ \\
\hline $\begin{array}{l}\text { Proneuronema gradatum Makarkin, } \\
\text { Wedmann et Weiterschan }\end{array}$ & Eocene, Baltic amber & Makarkin et al. 2016 \\
\hline $\begin{array}{l}\text { Proneuronema minor Makarkin, } \\
\text { Wedmann et Weiterschan }\end{array}$ & Eocene, Baltic amber & Makarkin et al. 2016 \\
\hline $\begin{array}{l}\text { Proneuronema wehri (Makarkin, } \\
\text { Archibald et Oswald) }\end{array}$ & Eocene, USA & $\begin{array}{l}\text { Makarkin et al. 2003; Makarkin et } \\
\text { al. } 2016\end{array}$ \\
\hline Prospadobius moestus (Hagen) & Eocene, Baltic amber & $\begin{array}{l}\text { Pictet-Baraban and Hagen 1856; } \\
\text { Krüger } 1923\end{array}$ \\
\hline $\begin{array}{l}\text { Sympherobius completus Makarkin and } \\
\text { Wedmann }\end{array}$ & Eocene, Baltic amber & Makarkin and Wedmann 2009 \\
\hline $\begin{array}{l}\text { Sympherobius siriae Jepson, Penney et } \\
\text { Green } 2010\end{array}$ & Eocene, Baltic amber & Jepson et al. 2010 \\
\hline $\begin{array}{l}\text { Wesmaelius mathewesi Makarkin, } \\
\text { Archibald et Oswald } 2003\end{array}$ & Eocene, Canada & Makarkin et al. 2003 \\
\hline Megalomus densistriatus Henriksen & Eocene, Denmark & Henriksen 1922 \\
\hline $\begin{array}{l}\text { Plesiorobius canadensis (Klimaszewski et } \\
\text { Kevan, 1986) }\end{array}$ & $\begin{array}{c}\text { Late Cretaceous, Canadian } \\
\text { amber }\end{array}$ & $\begin{array}{l}\text { Klimaszewski and Kevan 1986; } \\
\text { Makarkin et al. } 2016\end{array}$ \\
\hline Cretomerobius disjunctus Ponomarenko & $\begin{array}{l}\text { Early Cretaceous, } \\
\text { Mongolia }\end{array}$ & Ponomarenko 1992 \\
\hline $\begin{array}{l}\text { Purbemerobius medialis Jepson, Makarkin } \\
\text { et Coram }\end{array}$ & Early Cretaceous, England & Jepson et al. 2012 \\
\hline Promegalomus anomalus Panfilov & Late Jurassic, Kazakhstan & Panfilov 1980 \\
\hline
\end{tabular}

The specimen is housed in the collection of the Key Laboratory of Insect Evolution \& Environmental Changes, College of Life Sciences, Capital Normal University, Beijing, China (CNUB; Dong Ren, Curator).

The specimen was examined using a Zeiss Discovery V20 stereomicroscope and photographed with an AxioCam HRc digital camera attached to the Zeiss Discovery V20 stereomicroscope (both instruments Carl Zeiss Light Microscopy, Göttingen, Germany). Line drawings were prepared with the CorelDraw 12 graphics software and with the aid of Adobe Photoshop CS6. The vein terminology in general follows Yang et al. (2012, 2014). Terminology of wing spaces and details of venation (e.g., veinlets, traces, 'oblique radial branches' ("ORB”) concept) follows Oswald (1993). 
Venation abbreviations used in the text and figures:

\begin{tabular}{|c|c|c|c|}
\hline AA1-AA3 & first to third anterior anal & MP & posterior branche of media; \\
\hline & & ORB & ORB2, ORB3 first to thi \\
\hline $\mathrm{CuA}$ & anterior cubitus; & & oblique radial branches; \\
\hline $\mathrm{CuP}$ & posterior cubitus; & RA & anterior radius; \\
\hline hv & humeral veinlet; & $\mathbf{R P}$ & posterior sector; \\
\hline f & flexion fold line; & ScA & subcosta anterior; \\
\hline MA & anterior branche of media; & ScP & subcosta posterior. \\
\hline
\end{tabular}

\section{Systematic palaeontology}

Class Insecta Linnaeus, 1758

Order Neuroptera Linnaeus, 1758

Family Hemerobiidae Latreille, 1802

Subfamily Hemerobiinae Latreille, 1802

Genus Wesmaelius Krüger, 1922

Wesmaelius makarkini Yang, Pang \& Ren, sp. n.

http://zoobank.org/4B084F07-9F9E-4EDF-B900-31B2133F1F2F

Fig. 1

Holotype. CNU-NEU-QZ2017001 (holotype), a complete forewing (Fig. 1).

Diagnosis. Forewing with transparent spots on veins, and dark spots on the graduate crossveins, darker pigmentation along wing margin, subcostal veinlets, and longitudinal veins with dark intervals or dots. MA and MP pectinately forked, $2 \mathrm{~m}$-cu located at the fork of MA and $\mathrm{M}$, the crossveins of the third gradate series more oblique.

Description. Holotype CNU-NEU-QZ2017001. Only forewing preserved.

Forewing oval, $8.31 \mathrm{~mm}$ long, $3.17 \mathrm{~mm}$ wide. Trichosors prominent, along the entire wing margin. Setae distinct, scarce on the veins and dense on the margin. Costal space relatively broad, dilated basally. Humeral veinlet recurrent, with two pectinate branches. Presumable ScA present. Majority of subcostal veinlets branched once, several basal veinlets branched twice, with no crossveins between them. Subcostal space moderately broad, with two prestigmal sc-r crossveins: basal 1sc-r and distal 3sc-r. Posterior trace of RA forked apically, with two distal branches. One RA branch forked once, the other twice. RP with three branches (ORBs) originated from RA; ORB1with two pectinate branches between $3 \mathrm{r}-\mathrm{m}$ and $4 \mathrm{r}-\mathrm{m}$, all with distal forks; ORB2 dichotomously forked between the third and fourth gradate series of crossveins, each branch dichotomously forked; ORB3 forked between the second and third gradate series, with two dichotomously forked branches. $\mathrm{M}$ appear to be fused basally with R. M forked at $2 \mathrm{~m}-\mathrm{cu}$; MA, MP configuration similar, parallel for a long distance, then each with two pectinate branches between the third and fourth gradate series. The second branch of MP dichotomously forked. Forewing with three $\mathrm{m}$-cu crossveins. Crossvein $2 \mathrm{r}-\mathrm{m}$ present and positioned distally to crossvein $2 \mathrm{~m}$-cu; 

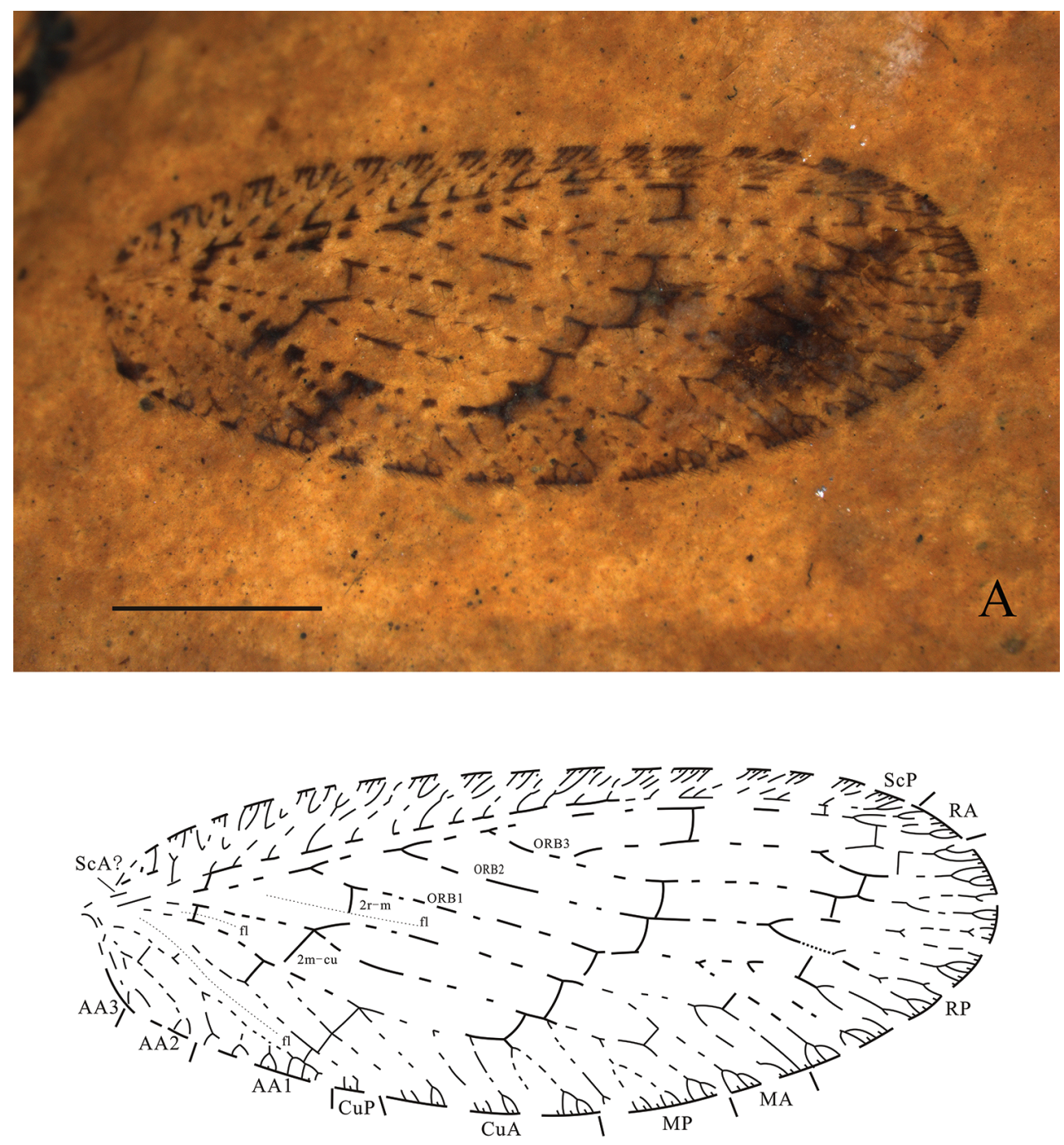

B

Figure I. Wesmaelius makarkini sp. n., holotype CNU-NEU-QZ2017001. A photograph of forewing under alcohol B Line drawing of forewing. Scale bars: $2 \mathrm{~mm}$.

$2 \mathrm{~m}-\mathrm{cu}$ at the fork of MA and MP. Cu divided into $\mathrm{CuA}$ and $\mathrm{CuP}$ proximal of the first gradate series, close to wing base; $\mathrm{CuA}$ with four pectinate branches distal to 2cua-cup, all branches with marginal forks; CuP simple, only with marginal fork. AA1 with three pectinate branches, all with marginal forks. AA2 with two simple branches, forked proximal to aa1-aa2. AA3 simple. Three flexion fold (line) distinct between RP and MA, MP and $\mathrm{CuA}, \mathrm{CuP}$ and $\mathrm{AA} 1$. The third gradate series with nine crossveins and the fourth gradate 
with seven crossveins. Forewing with transparent spots on veins, and dark spots at the graduate crossveins; margined with darker pigmentation, and no other distinct maculation; wing margin, subcostal veinlets and longitudinal veins with dark intervals or dots.

Etymology. The specific epithet is in honor of the entomologist Dr. Vladimir Nikolaevich Makarkin to acknowledge his great help to the first author in his study of Neuropteran.

Type locality and horizon. Caergen Village, Zeku County, Qinghai Province, China; Garang Formation; The early Miocene.

Remarks. The species can be easily attributed to the genus Wesmaelius due to the following characters: two prestigmal sc-r crossveins, three RP branches (ORBs), crossvein $2 \mathrm{r}-\mathrm{m}$ present and positioned distally to crossvein $2 \mathrm{~m}-\mathrm{cu}$; intersection of crossvein $2 \mathrm{~m}$-cu with $\mathrm{M}$ not more than the crossvein's length distal to fork MA/MP (sometimes anterior to this fork), resulting in cell $\mathrm{c} 2 \mathrm{~m}$-cu broad distally; forewing with three $\mathrm{m}$-cu crossveins (Oswald, 1993).

In the genus, Wesmaelius makarkini sp. n. is most similar to the extant species of $W$. nervosus (Fabricius, 1793), W. subnebulosus (Stephens, 1836) and W. reisseri U. Aspöck $\&$ H. Aspöck, 1982. The new species with two ORB3 branches, $2 \mathrm{~m}$-cu located at the division of MA and MP; while W. nervosus with three ORB3 branches, $2 \mathrm{~m}$-cu distal to the division of MA and MP; and W. makarkini with a distinct large darker pigmentation at the apex of forewing. The new species differs from W. subnebulosus and W. reisseri in the pectinately forked MA and RP1, 2m-cua located at the division of MA and MP, instead of dichotomously forked MA and RP1, and 2m-cu distal to the division of MA and MP in W. subnebulosus and W. reisseri. Moreover, the new species has seven crossveins in the fourth series, while $W$. reisseri has four crossveins.

\section{Discussion}

Named fossil Hemerobiidae have been described from the Late Jurassic to the Miocene, including four extinct genera from the Mesozoic and 11 genera from the Cenozoic (Table 1). Among the Cenozoic genera, six of them are extant genera, belonging to five subfamilies (Drepanepteryginae, Sympherobiinae, Megalominae, Hemerobiinae, Notiobiellinae), which are distributed in the three main clades of Hemerobiidae according to GarzónOrduña et al. (2016). The earliest fossil record of each of the five subfamilies are from the Eocene of Europe and North America, indicating these extant subfamilies have been well differentiated and widely distributed across the Northern hemisphere by the Eocene.

Wesmaelius is an extant genus with approximately 62 extant species and two fossil species from the Eocene of Canada (Makarkin et al. 2003) and the Miocene of China (as afore-described). The extant species are widely distributed in the Palearctic, Nearctic, Afrotropic, and Indomalaya, with the majority of species widely distributed across the northern hemisphere; only four species are found in the southern hemisphere (Makarkin et al. 2003; Oswald 2017). Nearly all of them are restricted from the tropical to the temperate zone, and most of them restricted to higher elevation montane region. 
The genus apparently is distributed from the north to the south, but the center of origin of Wesmaelius is questionable, mainly because the generic assignment of the oldest species (i.e., W. mathewesi) from the Eocene of Canada is uncertain (Makarkin et al. 2003). Nevertheless, W. mathewesi shows high affinity to the genera of Wesmaelius and Hemerobius, both of which belong to the subfamily Hemerobiinae. Therefore, it represents one of the earliest fossil records of the subfamily to date. Hemerobius also has fossil records extending back to the Miocene (Makarkin 1991). The geological history of the Hemerobiinae is still uncertain, due to the undetermined subfamilial assignment of the extinct genera, which requires further study.

\section{Acknowledgements}

We thank Dr. Chungkun Shih (College of Life Sciences, Capital Normal University and National Museum of Natural History, Smithsonian Institution) for his helpful comments, fruitful suggestion and improvement of our manuscript. We are grateful to Dr. Shaun L. Winterton (California State Arthropod Collection, California Department of Food and Agriculture, Sacramento, USA) for his kind help and permitting us to check the extant hemerobiids specimens. We sincerely thank Drs Yunzhi Yao and Junjie Gu, Zhipeng Zhao, Lei Li, Yizi Cao, Yingnan Li, Siyuan Wu, and He Tian for collecting specimens. We appreciate the valuable comments and useful suggestions on our manuscript from reviewers and the editor. This research was funded by grants from key project of Sciencetechnology basic condition platform from The Ministry of Science and Technology of the People's Republic of China (grant no. 2005DKA21402), the specimen platform of China, teaching specimens sub-platform, Web, http://mnh.scu.edu.cn/, National Natural Science Foundation of China (grant nos. 41602014, 31501881, 41402009, 31730087), China Postdoctoral Science Foundation (grant no. 2016M592570), Natural Science Foundation of Hebei Province (grant no. C2015403012), Basal Research Fund of SYSU (grant nos. 32110-41030349) and Program for Changjiang Scholars and Innovative Research Team in University (grant no. IRT-17R75).

\section{References}

Engel MS, Grimaldi DA (2007) The Neuropterid fauna of Dominican and Mexican amber

(Neuropterida: Megaloptera, Neuroptera). American Museum Novitates 3587: 1-58. https://doi.org/10.1206/0003-0082(2007)3587[1:TNFODA]2.0.CO;2

Fang XM, Yan MD, Van der Voo R, Rea DK, Song CH, Parés JM, Gao JP, Nie JP, Dai S (2005)

Late Cenozoic deformation and uplift of the NE Tibetan Plateau: Evidence from highresolution magnetostratigraphy of the guide basin, Qinghai province, China. Geological Society of America Bulletin 117: 1208-1225. https://doi.org/10.1130/B25727.1

Fang XM, Song CH, Dai S, Zhu YT, Gao JP, Zhang WL (2007) Cenozoic deformation and uplift of the NE Qinghai-Tibet Plateau: evidence from high-resolution magnetostratig- 
raphy and basin evolution. Earth Sciences Frontiers. 14: 230-242. [In Chinese, with English Abstract]

Garzón-Orduña IJ, Menchaca-Armenta I, Contreras-Ramos A, Liu XY, Winterton SL (2016) The phylogeny of brown lacewings (Neuroptera: Hemerobiidae) reveals multiple reductions in wing venation. BMC Evolutionary Biology 16(1):192. https://doi.org/10.1186/s12862-016-0746-5

Germar EF (1813) Insekten in Bernstein eingeschlossen, beschrieben aus dem academischen Mineralien-Cabinet zu Halle. Magazin der Entomologie 1: 11-18.

Guo SX (1980) Miocene flora in Zeku county of Qinghai. Acta Palaeontologica Sinica 19: 406-412.

Haring E, Aspöck U (2004) Phylogeny of Neuropterida: A first molecular approach. Systematic Entomology 29: 415-430. https://doi.org/10.1111/j.0307-6970.2004.00263.x

Henriksen KL (1922) Eocene insects from Denmark. Danmarks Geologiske Undersøgelse, 2 Række 37: 1-36.

Jarzembowski EA (1980) Fossil insects from the Bembridge Marls, Palaeogene of the Isle of Wight, southern England. Bulletin of the British Museum of Natural History (Geology) 33: 237-293.

Jepson JE, Makarkin VN, Coram RA (2012) Lacewings (Insecta: Neuroptera) from the Lower Cretaceous Purbeck Limestone Group of southern England. Cretaceous Research 34: 31-47. https://doi.org/10.1016/j.cretres.2011.10.001

Jepson JE, Penney D, Green DI (2010) A new species of brown lacewing (Neuroptera: Hemerobiidae) from Eocene Baltic amber. Zootaxa 2692: 61-68.

Klimaszewski J, Kevan DKM (1986) A new lacewing-fly (Neuroptera: Planipennia) from Canadian Cretaceous amber, with an analysis of its forewing characters. Entomological News 97(3): 124-132.

Krüger L (1922) Hemerobiidae. Beiträge zu einer Monographie der Neuropteren-Familie der Hemerobiiden. Stettiner Entomologische Zeitung 83: 138-172.

Krüger L (1923) Neuroptera succinica baltica. Die im baltischen Bernstein eingeschlossenen Neuroptera des Westpreussischen Provinzial-Museums (heute Museum für Naturkunde und Vorgeschichte) in Danzig. Stettiner Entomologische Zeitung 84: 68-92.

Latreille PA (1802) Histoire Naturelle, générale et particuliére des Crustacés et des Insectes Familles naturelles des genres. F. Dufart, Paris 3: 288-289.

Li XC, Xiao L, Lin ZC, He WL, Yang Q, Yao YZ, Ren D, Guo JF, Guo SX (2016) Fossil fruits of Koelreuteria (Sapindaceae) from the Miocene of northeastern Tibetan Plateau and their palaeoenvironmental, phytogeographic and phylogenetic implications. Review of Palaeobotany and Palynology 234: 125-135. https://doi.org/10.1016/j.revpalbo.2016.09.002

Li Y, Liu XH, Ren D, Li XC, Yao YZ (2017) First report of Cixiidae insect fossils from the Miocene of the northeastern Tibetan Plateau and their palaeoenvironmental implications, Alcheringa: An Australasian Journal of Palaeontology 41(1): 54-60. https://doi.org/10.1080 /03115518.2016.1180027

Linnaeus C (1758) Systema naturae per regna tria naturae secundum classes, ordines, genera, species, cum characteribus, differentiis, synonymis, locis. $10^{\text {th }} \mathrm{Ed}$, vol. 1 , Salvii, Holmiae, 824 pp.

Makarkin VN (1991) Miocene Neuroptera from the northern Caucasus and the Sikhote-Alin (Russian SFSR, USSR). Paleontologischeskii Zhurnal 1: 57-68. [In Russian] 
Makarkin VN, Archibald SB, Oswald JD (2003) New Early Eocene brown lacewings (Neuroptera: Hemerobiidae) from western North America. Canadian Entomologist 135(5): 637-653. https://doi.org/10.4039/n02-122

Makarkin VN, Wedmann S (2009) First record of the genus Sympherobius (Neuroptera: Hemerobiidae). Zootaxa 2078: 55-62.

Makarkin VN, Wedmann S, Weiterschan T (2012) First record of a fossil larva of Hemerobiidae (Neuroptera) from Baltic amber. Zootaxa 3417(2): 53-63.

Makarkin VN, Wedmann S, Weiterschan T (2016) A new genus of Hemerobiidae (Neuroptera) from Baltic amber, with a critical review of the Cenozoic Megalomus-like taxa and remarks on the wing venation variability of the family. Zootaxa 4179(3): 345-370. https://doi.org/10.11646/zootaxa.4179.3.2

Monserrat VJ (2000). New data on the Brown Lacewings from Asia (Neuroptera: Hemerobiidae). Journal of Neuropterology 3: 61-97.

Oswald JD (1993) Revision and cladistic analysis of the world genera of the family Hemerobiidae (Insecta: Neuroptera). Journal of the New York Entomological Society 101: 143-299.

Oswald JD (2000) The brown lacewing genus Notiobiella (Neuroptera: Hemerobiidae) from Dominican amber. Journal of the New York Entomological Society 107: 297-303.

Oswald JD (2017) Neuropterida Species of the World. Version 3.0. http://lacewing.tamu.edu/ Species-Catalogue/ [Accessed 30 June 2017]

Panfilov DV (1980) New representatives of lacewings (Neuroptera) from the Jurassic of Karatau. In: Dolin VG, Panfilov DV, Ponomarenko AG, Pritykina LN (Eds) Fossil insects of the Mesozoic: 82-111. Naukova Dumka, Kiev, 133 + [3] pp. [In Russian]

Pictet-Baraban FJ, Hagen H (1856) Die im Bernstein befindlichen Neuropteran der Vorwelt. In: Berendt GC (Ed.) Die im Berstein befindlichen organischen Reste der Vorwelt (2): 41126. Nicolaischen Buchhandlung, Berlin, [2] + 126 pp.

Ponomarenko AG (1992) New Neuroptera (Insecta, Neuroptera) of the Mesozoic of Mongolia. Trudy Sovmestnaya Sovetsko- Mongol'skaya Paleontologicheskaya Ekspeditsiya 41: 101111. [In Russian]

Scudder SH (1878) Additions to the insect fauna of the Tertiary beds at Quesnel (British Columbia). Report of Progress of the Geological Survey of Canada 1876-1877: 457-464.

Scudder SH (1890) The Tertiary Insects of North America. Report of the United States Geological Survey of the Territories 13: 1-734. [28 pls]

Stephens JF (1836) Illustrations of British entomology: or, a synopsis of indigenous insects: containing their generic and specific distinctions: with an account of their metamorphoses, times of appearance, localities, food and economy as far as practicable. Mandibulata. Baldwin and Cradock, London, vol 6, 240 pp.

Wang B, Rust J, Engel MS, Szwedo J, Dutta S, Nel A, Fan Y, Meng FW, Shi G, Jarzembowski EA, Wappler T, Stenber S, Fag Y, Mao LM, Zheng DR, Zhang HC (2014) A diverse paleobiota in Early Eocene Fushun amber from China. Current Biology 24: 1-5. https://doi.org/10.1016/j.cub.2014.05.048

Wang YY, Liu XY, Garzón-Orduña IJ, Winterton SL, Yan Y, Aspöck U, Aspöck H, Yang D (2017) Mitochondrial phylogenomics illuminates the evolutionary history of Neuropterida. Cladistics. https://doi.org/10.1111/cla.12186 
Winterton SL, Hardy NB, Wiegmann BM (2010) On wings of lace: phylogeny and Bayesian divergence times estimates of Neuropterida (Insecta) based on morphological and molecular data. Systematic Entomology 35: 349-378. https://doi.org/10.1111/j.1365-3113.2010.00521.x

Winterton SL, Lemmon A, Gillung JP, Garzon IJ, Badano D, Bakkes DK, Breitkreuz LCV, Engel MS, Lemmon EM, Liu XY, Machado RJP, Skevington JH, Oswald J (2017) Evolution of lacewings and allied orders using anchored phylogenomics (Neuroptera, Megaloptera, Raphidioptera). Systematic Entomology. https://doi.org/10.1111/syen.12278

Wise KAJ (1973) New records in the new Zealand Neuroptera: Hemerobiidae 5: 2, 181-185. Yang Q, Makarkin VN, Winterton SL, Khramov AV, Ren D (2012) A remarkable new family of Jurassic insects (Neuroptera) with primitive wing venation and its phylogenetic position in Neuropterida. PLoS ONE 7(9): e44762. http://dx.doi.org/10.1371/journal. pone. 0044762

Yang Q, Makarkin VN, Ren D (2014) Two new species of Kalligramma Walther (Neuroptera: Kalligrammatidae) from the Middle Jurassic of China. Annals of the Entomological Society of America 107: 917-925. https://doi.org/10.1603/AN14032

Young CC (1975) Feathers in the oil-bearing shales from the Tse-Ku-Tsa-Ka, Qinghai. Vertebrata Palasiatica 133: 163-164. 